\title{
Spatio-temporal distribution of fecal indicators in three rivers of the Haihe River Basin, China
}

\author{
Yawei Wang ${ }^{1}$ - Yanan Chen ${ }^{1,2} \cdot$ Xiang Zheng $^{2} \cdot$ Chengmin Gui $^{1} \cdot$ Yuansong Wei $^{1}$
}

Received: 30 June 2015 / Accepted: 30 November 2015 / Published online: 23 December 2015

(C) Springer-Verlag Berlin Heidelberg 2015

\begin{abstract}
Because of their significant impact on public health, waterborne pathogens, especially bacteria and viruses, are frequently monitored in surface water to assess microbial quality of water bodies. However, more than one billion people worldwide currently lack access to safe drinking water, and a diversity of waterborne outbreaks caused by pathogens is reported in nations at all levels of economic development. Spatio-temporal distribution of conventional pollutants and five pathogenic microorganisms were discussed for the Haihe River Basin. Land use and socio-economic assessments were coupled with comprehensive water quality monitoring. Physical, chemical, and biological parameters were measured at 20 different sites in the watershed for 1 year, including $\mathrm{pH}$, temperature, conductivity, dissolved oxygen, turbidity, chemical oxygen demand, ammonia-N, total and fecal coliforms, $E$. coli, and Enterococcus. The results highlighted the high spatio-temporal variability in pathogen distribution at watershed scale: high concentration of somatic coliphages and fecal indicator bacteria in March and December and their very low
\end{abstract}

Responsible editor: Philippe Garrigues

Electronic supplementary material The online version of this article (doi:10.1007/s11356-015-5907-3) contains supplementary material, which is available to authorized users.

Xiang Zheng

zhengxiang@ruc.edu.cn

Yuansong Wei

yswei@rcees.ac.cn

1 State Key Joint Laboratory of Environmental Simulation and Pollution Control, Research Center for Eco-Environmental Sciences, Chinese Academy of Sciences, Beijing 100085, China

2 School of Environment and Natural Resources, Renmin University of China, Beijing 100872, China concentration in June and September. All pathogens were positively correlated to urban/rural residential/industrial land and negatively correlated to other four land use types. Microbial pollution was greatly correlated with population density, urbanization rate, and percentage of the tertiary industry in the gross domestic product. In the future, river microbial risk control strategy should focus more on the effective management of secondary effluent of wastewater treatment plant and land around rivers.

Keywords Haihe rivers · Pathogens · Water quality · Spatio-temporal distribution $\cdot$ Land use

\section{Introduction}

Outbreaks of waterborne diseases via public water supplies continue to be reported in developed countries despite the increased awareness of and treatment for pathogen contamination (Brookes et al. 2004). According to the report of WHO (2009). an estimated $3 \%$ of all deaths worldwide are attributed to unsafe water consumption caused by poor sanitation. Beside health risks to humans, pathogen contamination can incur serious economic hardships on communities due to the closure of beaches or shellfish beds (Mitch et al. 2010). Currently, water quality of surface water in China is evaluated by conventional physical and chemical parameters; the pathogenic microorganism index is not regard as a compulsory parameter, although the pathogen index is listed in the current Chinese Surface Water Criteria (GB3838-2002). The fecal indicator microorganism (FIM) selected in China is fecal coliforms (FC), which is a different indicator from those used in the USA and the European Union. In general, the inclusion of FIM in the evaluation of surface water quality always downgrades the level of surface water quality by one to two grades 
(Hu et al. 2010; Lv et al. 2007). The literature data indicated that major river watersheds in China are affected by microbial contamination to some degree (Yang et al. 2012). Furthermore, ecological integrity includes structural integrity and functional integrity, the latter being influenced greatly by water quality (Chen et al. 2012). Although pathogens have great effect on water quality, they have not been considered in ecological integrity evaluations.

The levels of pathogens in surface water are influenced by many factors, mainly including point source and non-point source pollution. While the influence of point sources had been investigated quite well, the knowledge of pollution from non-point sources is still limited (Franke et al. 2009). especially in China. Among the non-point sources, the surrounding land use pattern is the major factor causing microbiological water quality degradation in surface water (George et al. 2004; Kistemann et al. 2002; Tong and Chen 2002). Land-based surface runoff, including storm runoff from impervious land cover and agricultural runoff following precipitation or irrigation, serves as a major pathway for transmission of contaminants (Converse et al. 2011; Morrison et al. 2008). In general, the levels of coliform bacteria in surface water are higher in commercial, residential, pasture, and agricultural lands, but lower in forest areas (Mehaffey et al. 2005). However, Diaz et al. (2010) conclude that in agricultural areas, receiving waters are likely to be contaminated by non-point pollution due to agricultural activities such as crop production, cattle operations, pastures, and rangeland. Better understanding of water pollution is urgently needed for the development of sitespecific mitigation strategies to reduce microbial pollution of water (Liang et al. 2013). However, to date, similar studies have been quite rare in China. As previously noted, surface water quality can be affected by land use, climate, topography, and geology associated with its catchment (Pratt and Chang 2012). The degradation of surface water quality can occur as a result of human activities, resulting in non-point (run off from urban and agricultural areas) and/or point source pollution (sewage treatment discharge and combined sewer overflow) (Sliva and Williams 2001). The intensification of agriculture has led to the production of large amounts of animal waste (from pigs, cows, and poultry) frequently spread onto fields as fertilizer and representing a potential source for fecal contamination of receiving waters (St Laurent and Mazumder 2012). Since the population size and economic development model have a great effect on the land use pattern, the effect of changes in the land use pattern on water microbial pollution warrants further studies.

The Haihe River, the largest water system in North China, flows through one of the most developed zones of China, receiving sewage water from populous and developed cities, such as Zhangjiakou, Beijing, and Tianjin, and discharging them into the Bohai Sea (Yang et al. 2005). With the rapid economic growth, industrialization, and urbanization, accompanied by insufficient infrastructure investment and management capacity, water pollution of the Haihe River has been the highest among Chinese rivers since 2000 according to the "Reports on the State of the Environment in China" (MOE 2015). The Haihe River Basin comprises three types of rivers: (1) the Yang River, in the upstream of the water source area, located in the mountainous area of Zhangjiakou, belongs to semi-arid areas; (2) the Wenyu River, located in suburban and urban areas of Beijing, drains nearly $70 \%$ of wastewater discharged by 20 million people living in the Chinese megacity Beijing (Heeb et al. 2012) and forms a large-scale irrigation system severely impacted by wastewater-borne pollution, thus becoming the representative of new river type caused by excessive development and utilization of water resources; and (3) the Beiyun River (North Canal and Yongding River, Fig. 1), located in the downstream of the watershed, mainly used for agricultural irrigation.

Water quality of these rivers is important for the health of the population living in this basin, and it is influenced by many factors. To protect the environment and public health and to establish specific, workable river management strategy, it is essential to know the sources and types of pathogen contamination and determine the factors affecting the pathogens.

Therefore, the objectives of this study were to: (1) identify the overall pollutant feature of rivers in the Haihe River Basin; (2) evaluate the characteristics of four kinds of FIM in the three river types; and (3) analyze the factors affecting the pathogenic contamination, i.e., land use and socio-economic development in the large watershed. In order to achieve these objectives, a comprehensive field investigation was carried out throughout a period of 1 year to analyze spatio-temporal distribution of four kinds of FIM, bacteriophages, and other physiochemical parameters (i.e., chemical oxygen demand [COD], ammonia nitrogen $\left[\mathrm{NH}_{3}-\mathrm{N}\right], \mathrm{pH}$, and others) and to correlate pathogen contamination with physiochemical parameters, land use, population size, and economic development, which will facilitate future watershed management strategies.

\section{Methods}

\section{Study areas}

The Haihe River Basin (discharging into the Bohai Sea) is the largest water system in northern China. It drains an area of $265,000 \mathrm{~km}^{2}$ that includes the economically fastest growing region of China as well as $120,000 \mathrm{~km}^{2}$ of farmland (Luo et al. 2011; Pernet-Coudrier et al. 2012). The investigated area in our study is shown in Fig. 1, including the three types of rivers. The lengths and flows were $118 \mathrm{~km}$ and $3.80 \mathrm{~m}^{3} / \mathrm{s}$ (average of year 2013, data source: Zhangjiakou Environmental Protection Bureau) of the Yang River, 


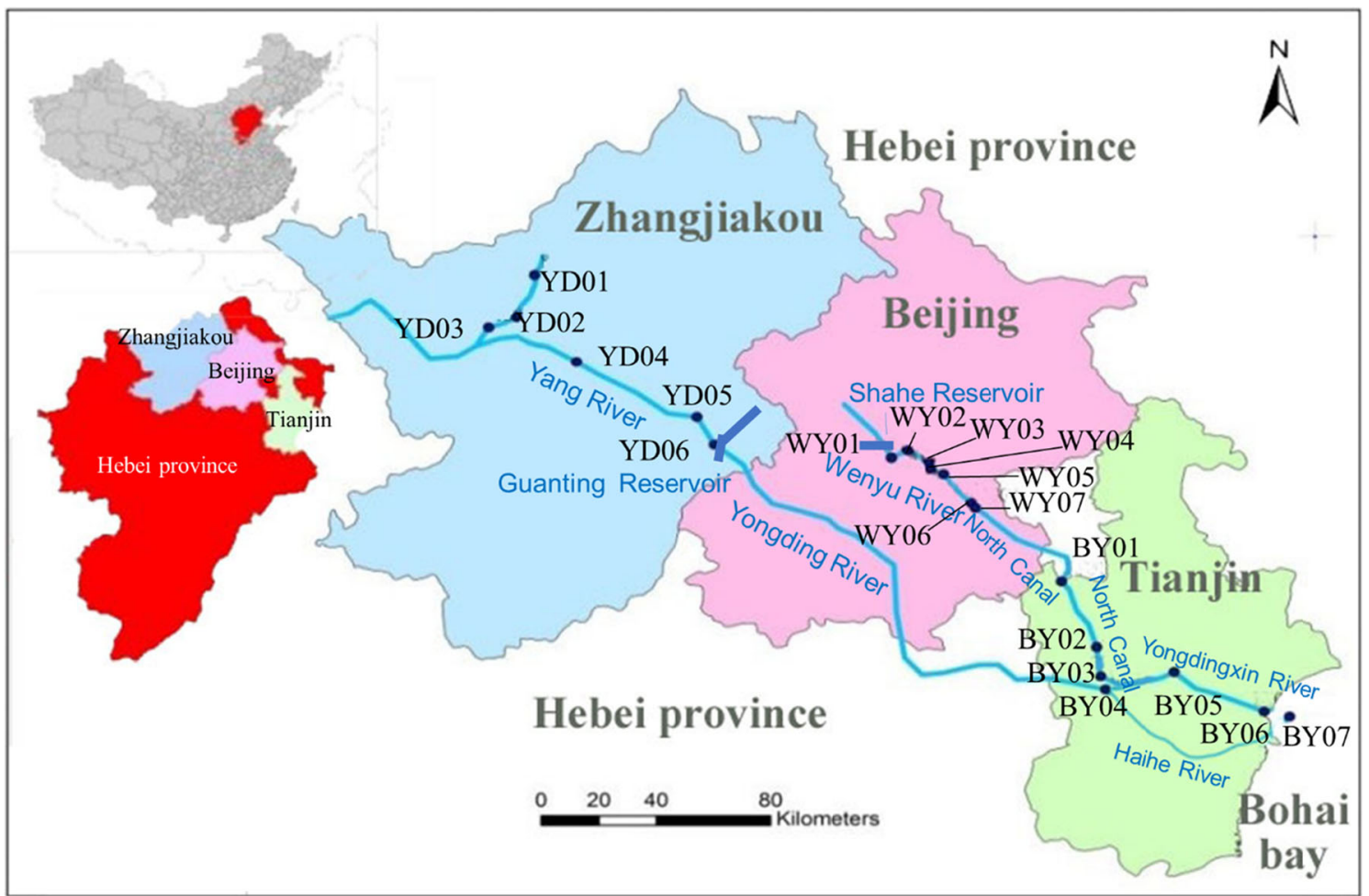

Fig. 1 Study area of the Haihe River Basin and location of sampling sites

$47.5 \mathrm{~km}$ and $22.9 \mathrm{~m}^{3} / \mathrm{s}$ of the Wenyu River, and $192.5 \mathrm{~km}$ and $18.5 \mathrm{~m}^{3} / \mathrm{s}$ of the Beiyun River (Heeb et al. 2012). respectively. For a comprehensive evaluation of the microbiological quality of the Haihe River Basin waters, 20 sampling sites were selected (Fig. 1 and Table 1). The sampling site YD06 indicates the Guanting Reservoir, the standby drinking water source of Beijing. BY07 indicates the coast of Bohai bay.

\section{Field investigation methods}

River water samples were taken every 4 months from December 2013 to December 2014 by scooping water out of the river center and storing it in two 1.5-L sterile polyethylene bottles. Samples were placed on ice packs in portable coolers and transported to the laboratory, where they were stored at $4{ }^{\circ} \mathrm{C}$. The analysis of the microorganisms was done within $24 \mathrm{~h}$ of sampling time.

\section{Detection method}

Conventional physicochemical parameters including water temperature, ambient temperature, humidity, dissolved oxygen (DO), $\mathrm{pH}$, conductivity, salinity, turbidity, $\mathrm{COD}, \mathrm{NH}_{3^{-}}$ $\mathrm{N}$, nitrate nitrogen, phosphate, and suspended solids were measured for all water samples. Water temperature, ambient temperature, humidity, and DO were measured on-site, and other parameters were determined in laboratory according to the Chinese Surface Water Criteria (GB3838-2002); the details are provided in Table $\mathrm{S} 1$ in supplementary information.

Total coliform (TC) is the only pathogenic microorganism indicator in surface water criteria adopted by France, Japan, Ecuador, and China (WHO 2000). and fecal coliform (FC) is the only pathogenic indicator adopted in Chinese Surface Water Criteria (GB3838-2002); E. coli (EC) and Enterococcus (ENT) are selected as pathogenic microorganism indicators in surface water criteria of the Environmental Protection Agency of the United State (USEPA), the European Union (EU), and the World Health Organization (WHO) (Chen et al. 2015). Each of these indicators is used to reflect pathogenic pollution of fresh water within limits set according to water function and grade. To evaluate water quality of the Haihe River Basin, somatic coliphages (SC) and the four types of indicators (TC, FC, EC, and ENT) were selected. Enumeration of TC and FC in surface water samples was conducted according to the standard method (APHA 1998). Briefly, water samples were filtered through a $0.45-\mu \mathrm{m}$ pore size filter. For TC measurement, the prepared filters were directly placed onto absorbent pads soaked with $\mathrm{m}$-Endo medium on culture dishes, and the inverted dishes were incubated for 22 to $24 \mathrm{~h}$ at $35 \pm 0.5^{\circ} \mathrm{C}$. Colonies showing a pink to dark red color with a metallic surface sheen were defined as typical coliforms, while the dark red, mucoid, or nucleated without sheen are considered atypical coliforms. Both the typical and atypical coliform colonies were verified using lauryl tryptose broth and brilliant green lactose broth. For FC counting, m-FC 
Table 1 Chemical oxygen demand (COD) and $\mathrm{NH}_{3}-\mathrm{N}$ pollution of all sampling sites (mean $\pm \mathrm{SD}$ )

\begin{tabular}{|c|c|c|c|c|c|c|c|}
\hline & & Longitude (E) & Latitude $(\mathrm{N})$ & Altitude (m) & $\begin{array}{l}\mathrm{COD} \\
\mathrm{mg} / \mathrm{L}\end{array}$ & $\begin{array}{l}\mathrm{NH}_{3}-\mathrm{N} \\
\mathrm{mg} / \mathrm{L}\end{array}$ & $\begin{array}{l}\mathrm{FC} \\
\mathrm{CFU} / \mathrm{mL}\end{array}$ \\
\hline \multirow{6}{*}{ Yang River } & YD01 & $114^{\circ} 56^{\prime} 28^{\prime \prime}$ & $40^{\circ} 53^{\prime} 18^{\prime \prime}$ & 851 & $28.00 \pm 14.14$ & $0.42 \pm 0.35$ & $2.09 \pm 2.97$ \\
\hline & YD02 & $114^{\circ} 50^{\prime} 36^{\prime \prime}$ & $40^{\circ} 44^{\prime} 48^{\prime \prime}$ & 685 & $27.75 \pm 23.77$ & $1.42 \pm 0.29$ & $0.75 \pm 1.50$ \\
\hline & YD03 & $114^{\circ} 43^{\prime} 19^{\prime \prime}$ & $40^{\circ} 43^{\prime} 09^{\prime \prime}$ & 678 & $17.00 \pm 8.08$ & $0.49 \pm 0.47$ & $125.12 \pm 249.91$ \\
\hline & YD04 & $115^{\circ} 04^{\prime} 23^{\prime \prime}$ & $40^{\circ} 34^{\prime} 20^{\prime \prime}$ & 583 & $36.25 \pm 41.73$ & $0.64 \pm 0.41$ & $1 \pm 2$ \\
\hline & YD05 & $115^{\circ} 32^{\prime} 51^{\prime \prime}$ & $40^{\circ} 20^{\prime} 20^{\prime \prime}$ & 470 & $19.50 \pm 17.02$ & $0.70 \pm 0.28$ & $7.25 \pm 13.84$ \\
\hline & YD06 & $115^{\circ} 36^{\prime} 21^{\prime \prime}$ & $40^{\circ} 14^{\prime} 13^{\prime \prime}$ & 468 & $36.00 \pm 13.88$ & $0.62 \pm 0.38$ & $7.63 \pm 15.25$ \\
\hline \multirow[t]{7}{*}{ Wenyu River } & WY01 & $116^{\circ} 19^{\prime} 58^{\prime \prime}$ & $40^{\circ} 07^{\prime} 52^{\prime \prime}$ & 35 & $33.75 \pm 19.02$ & $8.42 \pm 4.11$ & $16.75 \pm 19.62$ \\
\hline & WY02 & $116^{\circ} 24^{\prime} 18^{\prime \prime}$ & $40^{\circ} 09^{\prime} 02^{\prime \prime}$ & 28 & $32.00 \pm 21.07$ & $9.31 \pm 6.41$ & $1007.63 \pm 1129.09$ \\
\hline & WY03 & $116^{\circ} 29^{\prime} 10^{\prime \prime}$ & $40^{\circ} 06^{\prime} 14^{\prime \prime}$ & 37.3 & $32.50 \pm 24.17$ & $9.87 \pm 5.74$ & $3.5 \pm 3.67$ \\
\hline & WY04 & $116^{\circ} 29^{\prime} 21^{\prime \prime}$ & $40^{\circ} 04^{\prime} 45^{\prime \prime}$ & 39 & $29.75 \pm 14.73$ & $9.65 \pm 4.50$ & $1278.75 \pm 2165.60$ \\
\hline & WY05 & $116^{\circ} 32^{\prime} 20^{\prime \prime}$ & $40^{\circ} 03^{\prime} 20^{\prime \prime}$ & 27 & $36.50 \pm 15.93$ & $8.80 \pm 3.18$ & $121.13 \pm 167.35$ \\
\hline & WY06 & $116^{\circ} 38^{\prime} 13^{\prime \prime}$ & $39^{\circ} 56^{\prime} 45^{\prime \prime}$ & 22 & $39.50 \pm 6.66$ & $8.51 \pm 2.33$ & $90.18 \pm 156.67$ \\
\hline & WY07 & $116^{\circ} 39^{\prime} 06^{\prime \prime}$ & $39^{\circ} 55^{\prime} 37^{\prime \prime}$ & 15 & $34.75 \pm 10.97$ & $10.12 \pm 1.75$ & $1.75 \pm 3.18$ \\
\hline \multirow[t]{7}{*}{ Beiyun River } & BY01 & $116^{\circ} 58^{\prime} 08^{\prime \prime}$ & $39^{\circ} 38^{\prime} 15^{\prime \prime}$ & 18 & $33.50 \pm 13.18$ & $10.89 \pm 3.51$ & $0.51 \pm 0.99$ \\
\hline & BY02 & $117^{\circ} 04^{\prime} 33^{\prime \prime}$ & $39^{\circ} 23^{\prime} 46^{\prime \prime}$ & 7 & $32.50 \pm 16.38$ & $3.34 \pm 1.92$ & $2.73 \pm 4.87$ \\
\hline & BY03 & $117^{\circ} 04^{\prime} 33^{\prime \prime}$ & $39^{\circ} 17^{\prime} 36^{\prime \prime}$ & 8 & $24.75 \pm 8.92$ & $1.40 \pm 0.54$ & $1.75 \pm 3.5$ \\
\hline & BY04 & $117^{\circ} 05^{\prime} 19^{\prime \prime}$ & $39^{\circ} 14^{\prime} 42^{\prime \prime}$ & 8 & $34.50 \pm 11.90$ & $3.23 \pm 1.17$ & $1.02 \pm 1.98$ \\
\hline & BY05 & $117^{\circ} 22^{\prime} 49^{\prime \prime}$ & $39^{\circ} 16^{\prime} 46^{\prime \prime}$ & 3 & $28.50 \pm 12.40$ & $6.77 \pm 2.34$ & $0.58 \pm 0.96$ \\
\hline & BY06 & $117^{\circ} 43^{\prime} 23^{\prime \prime}$ & $39^{\circ} 06^{\prime} 26^{\prime \prime}$ & -3 & $44.00 \pm 9.90$ & $5.11 \pm 1.67$ & $4.25 \pm 7.84$ \\
\hline & BY07 & $117^{\circ} 49^{\prime} 24^{\prime \prime}$ & $39^{\circ} 04^{\prime} 46^{\prime \prime}$ & 0 & N/A & $1.69 \pm 0.75$ & $0.25 \pm 0.5$ \\
\hline
\end{tabular}

Criteria of Grade V are $40 \mathrm{mg} / \mathrm{L}$ of COD, $2 \mathrm{mg} / \mathrm{L}$ of $\mathrm{NH}_{3}-\mathrm{N}$, and $40 \mathrm{CFU} / \mathrm{mL}$ of FC according to the Chinese Surface Water Criteria (GB3838-2002)

medium was used instead of $\mathrm{m}$-Endo medium, and the dishes were incubated at $44.5 \pm 0.5^{\circ} \mathrm{C}$ for $24 \pm 2 \mathrm{~h}$. Colonies showing various shades of blue on the m-FC medium and confirmed with lauryl tryptose broth and EC broth were identified as FC and enumerated. E. Coli and ENT were analyzed according to USEPA (1985). Water samples $(100 \mathrm{~mL})$ were analyzed according to manufacturer's instructions as below; positive $(E$. coli ATCC 11775) and negative (Pseudomonas aeruginosa ATCC 10145) controls were used for all samples analyzed with Colilert 18 (IDEX Laboratories, Inc., Westbrook, MA, USA). Similarly, the positive (Enterococcus faecium ATCC 35667) and negative (Serratia marcescens ATCC 43862) controls were used for Enterolert (IDEX, USA). Concentrations of EC and ENT in river water were expressed as most probable number (MPN)/100 mL.

The SC were analyzed using the double-layer technique of EN ISO 10705-2 with E. coli WG5 (the host bacteria of SC) (ISO 2010). Melt bottles of 50-mL semi-solid modified Scholtens' agar (ssMSA) kept in a boiling water bath were transferred in a water bath at $45 \pm 1{ }^{\circ} \mathrm{C}$. Calcium chloride solution $(300 \mu \mathrm{L})$ pre-warmed at room temperature was aseptically added, and $2.5-\mathrm{mL}$ aliquots were then distributed into culture tubes with caps placed in a water bath at $45 \pm 1{ }^{\circ} \mathrm{C}$. Original sample (or diluted or concentrated sample) $(1 \mathrm{~mL})$, pre-warmed at room temperature, was added to each culture tube. Inoculum culture $(1 \mathrm{~mL})$ was added to each culture tube containing the sample aliquots and ssMSA, mixed carefully to avoid formation of air bubbles, and the content was poured on a layer of complete MSA in a 9-cm Petri dish pre-warmed at room temperature. The content was distributed evenly and allowed to solidify on a horizontal, cool surface. The plates were dried by incubating with partially opened lids, then covered and incubated upside-down at $36 \pm 2{ }^{\circ} \mathrm{C}$ for $18 \pm 2 \mathrm{~h}$. The number of plaques was counted on each plate within $4 \mathrm{~h}$ after finishing incubation. The bacteriological parameters were examined using standard detection methods.

\section{Data source}

The land cover and land use were determined for the Haihe River Basin in Tianjin, Beijing, and Zhangjiakou, the three cities located along the three rivers, and in the perimeter of $10 \mathrm{~km}$ around each sampling site using ArcGIS (ESRI, Redlands, CA, USA) and the Haihe Land Cover 2008 provided by the Data Center for Resources and Environmental Sciences, Chinese Academy of Sciences. The data sets were produced by visual interpretation of Landsat TM/ETM remote sensing images collected in the late 1980s, 1990, 1995, 2000, 2005 , and 2008. The identified classes were aggregated into six primary types and 25 secondary types. 
Socio-economic data were derived from "Tianjin Statistical Yearbook of 2013," "Beijing Statistics Yearbook of 2013," "Statistics Yearbook of 2013," and website of the Hebei Bureau of Statistics (http://www.hetj.gov.cn/).

\section{Statistical analysis}

Statistical analysis of the data was conducted with SPSS Statistics 19.0 (IBM Corp., Armonk, NY, USA). The Spearman's rank correlation coefficient $\left(r_{\mathrm{s}}\right)$ was used to determine the correlation between FIM and physical and chemical parameters of the water and environmental variables. Only those environmental parameters that showed significant differences or correlation at $p \leq 0.05$ were reported. A two-step strategy was used for the correlation analysis between bacteria and environmental variables, and Pearson regression and logistic regression were performed to test the bivariate associations as described by Walters et al. (2011). Redundancy analysis was used to analyze land use type.

\section{Results and discussion}

\section{Water pollution of the three rivers}

To evaluate water pollution in the three rivers of the Haihe River Basin, concentrations of COD and $\mathrm{NH}_{3}-\mathrm{N}$ were investigated in four seasons, and the results of water quality analysis based on $\mathrm{COD}+\mathrm{NH}_{3}-\mathrm{N}$ and $\mathrm{COD}+\mathrm{NH}_{3}-\mathrm{N}+\mathrm{FC}$ are described in Table 1 and shown in Fig. 2. Ammonia nitrogen $\left(\mathrm{NH}_{3}-\mathrm{N}\right)$ and $\mathrm{COD}$ are major pollutants of industrial and domestic pollution sources in the Haihe River Basin (MOE 2010a). The numbers of sample in which $\mathrm{COD}$ and $\mathrm{NH}_{3}-\mathrm{N}$ concentration exceeded the surface water criteria of Grade $\mathrm{V}$ (lose all designated uses, Table S1), were 21 (COD) and 58 $\left(\mathrm{NH}_{3}-\mathrm{N}\right)$ of total 80 samples (Table $\mathrm{S} 2$ ), respectively. The concentration of $\mathrm{NH}_{3}-\mathrm{N}$ in the Haihe River Basin was the highest in Beijing, followed by Tianjin and then Zhangjiakou, whereas the concentration of COD was not significantly different between the sampling sites. The temporal distribution of $\mathrm{COD}$ and $\mathrm{NH}_{3}-\mathrm{N}$ was significant; it followed a decreasing pattern from spring to summer, winter, and finally fall for COD and from winter to spring, summer, and autumn for $\mathrm{NH}_{3}-\mathrm{N}$.

Water quality inferred from the concentrations of $\mathrm{COD}+$ $\mathrm{NH}_{3}-\mathrm{N}$ and $\mathrm{COD}+\mathrm{NH}_{3}-\mathrm{N}+\mathrm{FC}$ was significantly different between the sampling sites (Fig. 2). Thus, the water quality evaluated using $\mathrm{COD}+\mathrm{NH}_{3}-\mathrm{N}$ was worser than Grade $\mathrm{V}$ in nearly $70 \%$ of sampling sites. The inclusion of FC in the evaluation indexes further degrades the water quality, especially at sites with heavy pollution. At some sites, concentration of pathogens was hundreds of times above the upper limit of the worst surface water quality.
A significant number of studies showed that surface water quality should be evaluated not only by conventional physical and chemical parameters but also by using biological parameters. For example, in 2003, among the six sections monitored in the reservoir area of the Three Gorges, one was classified as Grade III (MOE 2003). and the other five as Grade II. However, after including FC, their water quality fell to Grade IV and V, respectively (Lv et al. 2007). Similarly, in 2010, water quality of the Guangzhou section of the Pear River was categorized as Grade II (MOE 2010b) and after including FC, it was classified as worser than Grade V, since the concentration of $\mathrm{FC}$ was two orders of magnitude greater than that of Grade V (Hu et al. 2010). In general, the inclusion of the pathogenic index reduces the degree of surface water quality by one to two grades, which in turn affects the available usage of surface water and its value to people. Therefore, pathogenic index plays a great role in the assessment of water quality and ecological integrity of the rivers, and it should be always considered in the evaluations.

\section{Spatio-temporal distribution of different pathogens}

\section{Total coliforms and fecal coliforms}

The spatio-temporal distribution of TC and FC in these three rivers is shown in Fig. 3. The number of TCs ranged from 0 to $4.5 \times 10^{5}$ colony forming units $(\mathrm{CFU}) / 100 \mathrm{~mL}$ and that of FCs from 0 to $2.0 \times 10^{5} \mathrm{CFU} / 100 \mathrm{~mL}$. Using the surface water criteria (TC) of other countries, the microbial pollution in $50 \%$ of sampling sites in the Haihe River Basin was beyond the upper limits. According to the grading scale adopted in China, most of the sampling sites did not meet the water quality criteria (Grade V, agricultural use and basic landscape water, Table S1).

Overall, the frequency and concentration of TC were higher than those of FC, since FC belongs to the category of $\mathrm{TC}$ and it mainly originates from the droppings of warmblooded animals; therefore, FC is preferable indicator of fecal pollution. The Wenyu River located in Beijing contained the highest concentration of $\mathrm{FC}$, especially at the Qinghe River mouth (WY04), Ma Fang bridge (WY02), and the Bahe River (WY06) (Fig. 3). The microbial pollution in the three rivers was the highest in the autumn (September), whereas there was no significant difference in the concentration in other three seasons at less than $5 \times 10^{2} \mathrm{CFU} / \mathrm{mL}$.

Lee et al. (2013) reported that the number of TCs in rivers ranged from 0 to $1.2 \times 10^{5} \mathrm{CFU} / 100 \mathrm{~mL}$ and that of FCs from 0 to $6.2 \times 10^{3} \mathrm{CFU} / 100 \mathrm{~mL}$ in Korea (Lee et al. 2013). TC concentration decreased in the order summer $>$ autumn $>$ winter $>$ spring, and $\mathrm{FC}$ concentration decreased in the order autumn $>$ summer $>$ spring $>$ winter. Similar trend was observed in this study (Figure S1). According to the limits set by the Chinese Surface Water Criteria (GB3838-2002), 

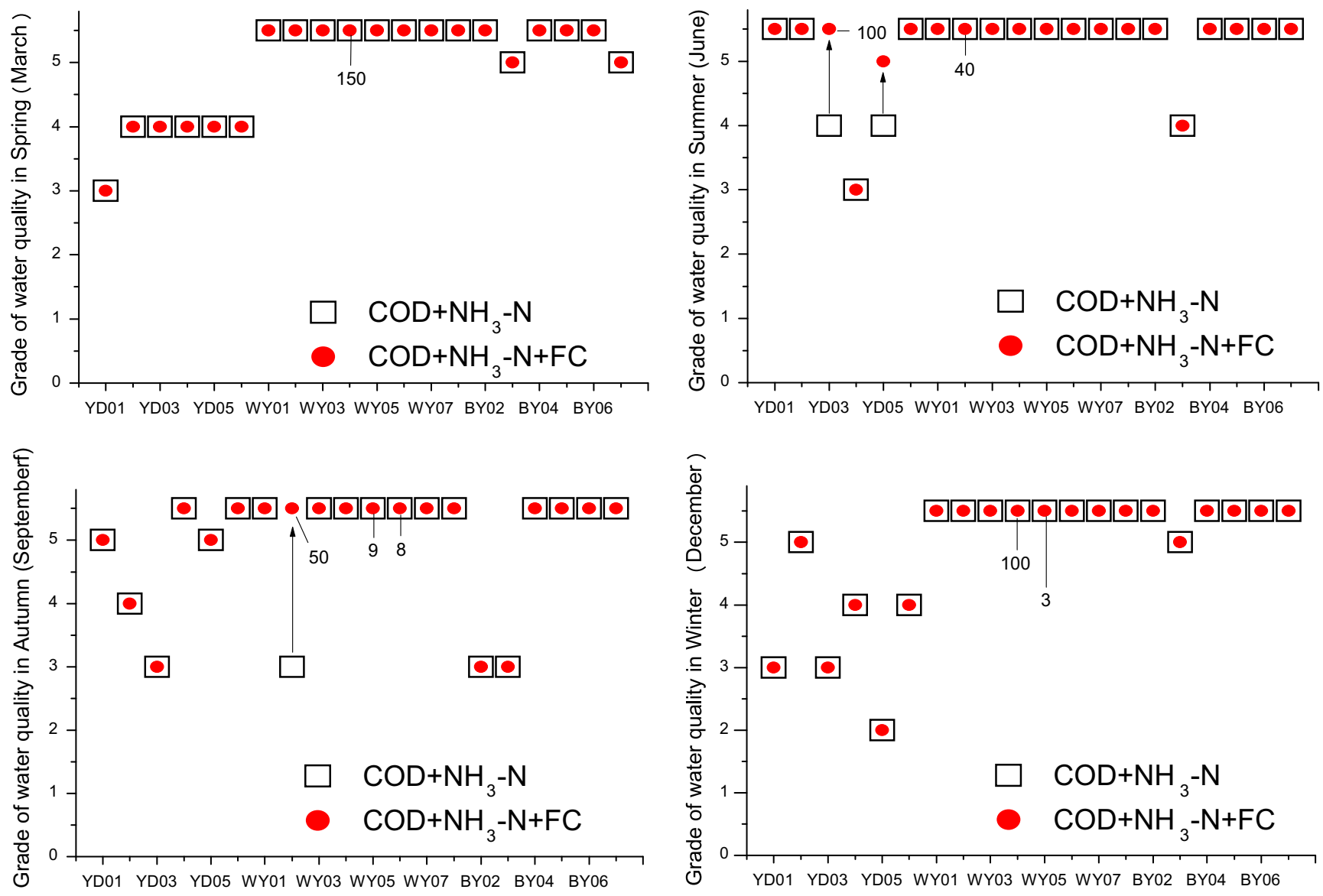

Fig. 2 Grade of water quality in the three rivers in different seasons. Numbers in the figures mean the multiple of FC detected by the limits for Grade V according to the China Water Quality Standard. The squares

indicate the grade of water quality evaluated by " $\mathrm{COD}+\mathrm{NH}_{3}-\mathrm{N}$;" the solid circles indicate the grade of water quality evaluated by " $\mathrm{COD}+$ $\mathrm{NH}_{3}-\mathrm{N}+\mathrm{FC} "$

concentration of FC at the Qinghe River mouth (WY04) exceeded 1000-fold the upper limit of the Grade V in winter. WY04 site represents the influence of wastewater treatment plant effluent, which makes up a very large proportion of the river flow. The operation of sewage treatment plants was responsible for the pollution observed at sampling sites. Although such an increase appeared occasionally, its risks on human health cannot be ignored.

\section{E. coli and Enterococcus}

According to the surface water criteria of the USEPA (2012), EU (2006), and WHO (2000), water quality in most of the areas in the Haihe River Basin does not meet the requirements of recreational waters with primary contact.

Similar to TC/FC contamination, the river in Beijing section was affected by the highest EC and ENT pollution (Fig. 4), in particular the sampling sites at the Qinghe River mouth (WY04), Ma Fang River bridge (WY02), and the Bahe River (WY06); the highest frequency and concentration of EC and ENT occurred in autumn (September) at 95 and $45 \%$ of the

sampling sites, respectively. Such increased concentration of EC and ENT in autumn may be due to warm water temperatures that ranged between 15.7 and $25^{\circ} \mathrm{C}$, which temperatures are more suitable for microbial growth. Overall, TC, FC, EC, and ENT had similar spatio-temporal distribution characteristics, with the most severe microbial pollution observed in Beijing section.

\section{Somatic coliphages}

Figure 5 shows the spatio-temporal distribution of $\mathrm{SC}$ in the three rivers during the four seasons. Concentration of SC significantly varied between sampling sites; it was the highest at samples collected in Beijing, followed by the samples in Tianjin and then in Zhangiiakou. Similar spatial pattern was observed for $\mathrm{NH}_{3}-\mathrm{N}$. Independent of the season, $\mathrm{SC}$ concentration was the highest in spring, followed by that in winter, summer, and the lowest was in autumn; this temporal pattern was somewhat different from that observed for COD and $\mathrm{NH}_{3}-\mathrm{N}$. For a long time, $\mathrm{FC}$ was used as indicator of microbial pollution in surface water criteria, while many studies had shown that FC did not reflect the effects of viruses and 
Fig. 3 Spatio-temporal distribution of total coliform (TC) (a) and fecal coliform (FC) (b) in the three rivers
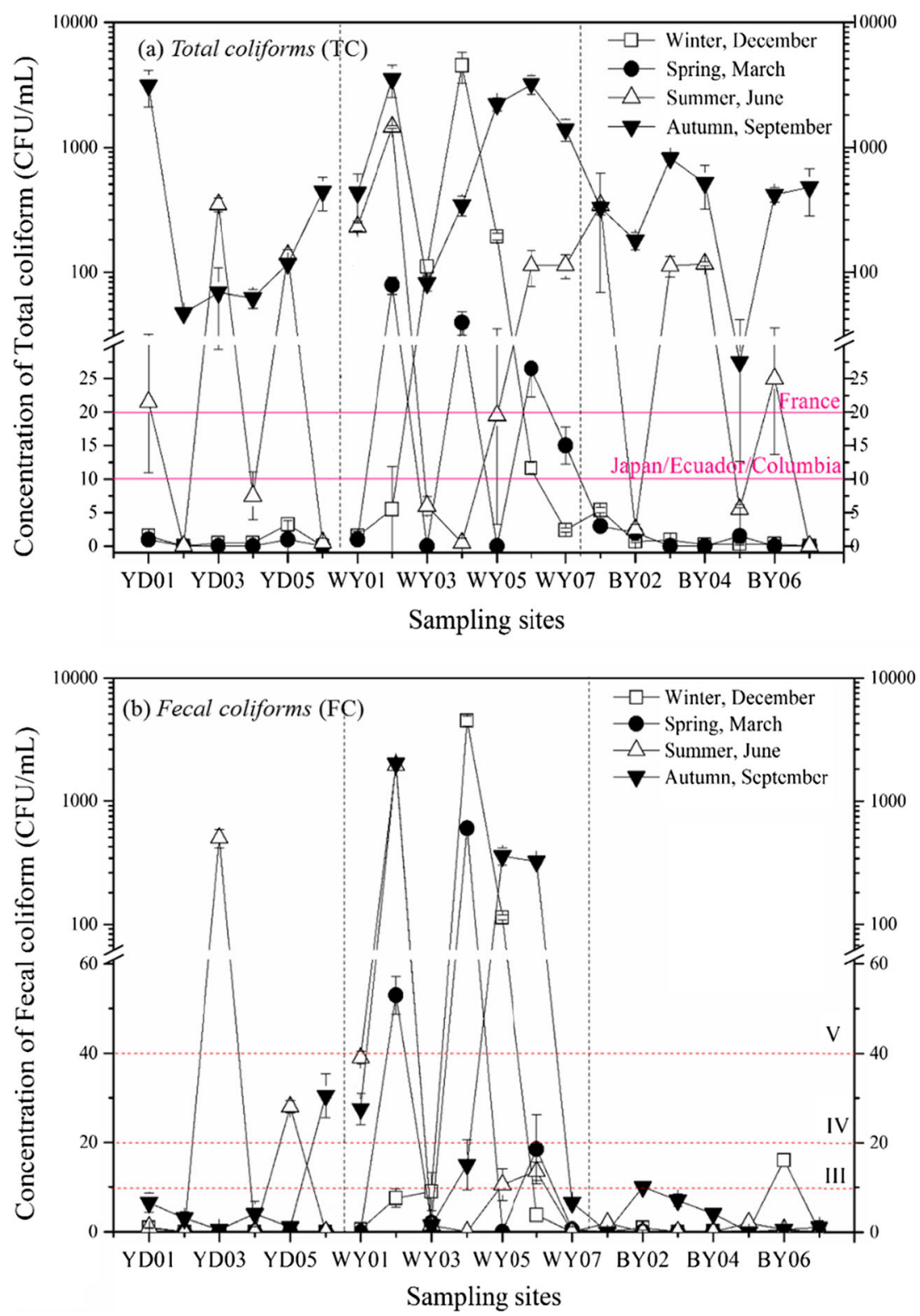

Physicochemical parameters of water quality

protozoa (Byamukama et al. 2005). Due to its morphological characteristics, persistence in water environment and resistance to water treatment, $E$. coli phage represented by SC is very similar to the intestinal virus (Chung et al. 1998). It is widespread in human and animal waste and polluted water bodies and therefore often used as indicator of the viruses. Another study (Li et al. 2006) indicated that concentration of $\mathrm{SC}$ in the influent of wastewater treatment plant with removal rate of $72.45-99.89 \%$ can reach up to $6.25 \times 10^{4}$ plaque forming units $(\mathrm{PFU}) / \mathrm{mL}$, indicating that large amounts of $\mathrm{SC}$ still existed in effluent. Therefore, SC can reflect the virus pollution in a river to a certain degree. In our study, concentrations of SC in some sampling sites located in Beijing were rather high and only slightly lower than those in the influent of wastewater treatment plant.
Environmental hydrological factors, such as water temperature, $\mathrm{pH}, \mathrm{DO}$, and water quality parameters, including COD, ammonia nitrogen, and phosphate, may affect the survival of pathogenic microorganisms. All the physicochemical indexes are provided in Table S2 in supplementary information document. The effect of common environmental factors on pathogens was assessed using Pearson correlation coefficient analysis (Table 2). FC and SC were significantly correlated with the physicochemical parameters of water quality; FC was positively correlated with phosphate $\left(r^{2}=0.235\right.$, $p \leq 0.05)$ and $\mathrm{NH}_{3}-\mathrm{N}\left(r^{2}=0.274, p \leq 0.05\right)$, and $\mathrm{SC}$ was negatively correlated with $\mathrm{pH}\left(r^{2}=0.288, p \leq 0.01\right)$ and 
Fig. 4 Spatio-temporal distribution of E. coli (EC) (a) and Enterococcus (ENT) (b) in the three rivers
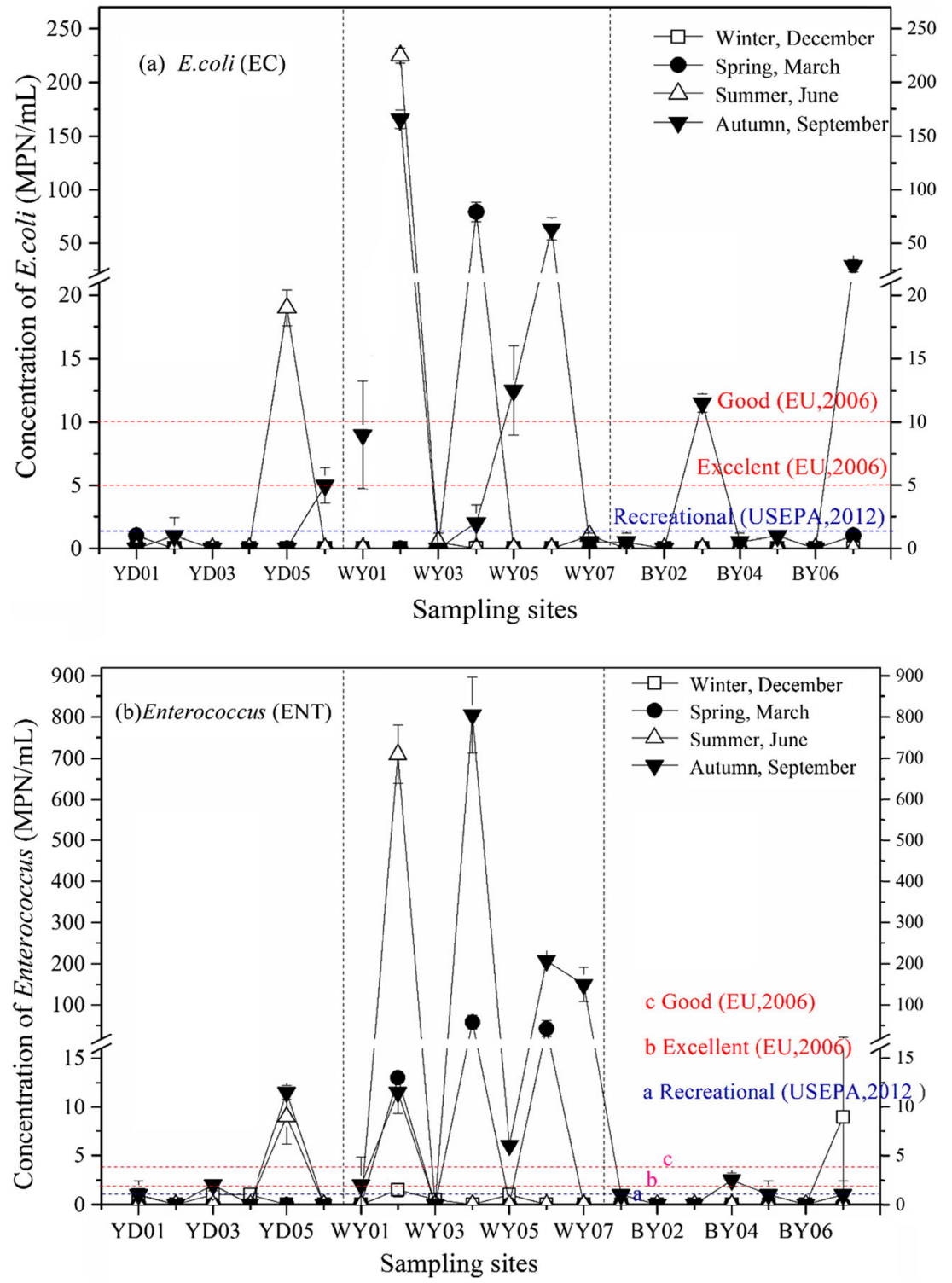

DO $\left(r^{2}=0.387, p \leq 0.01\right)$. Among the indicator microorganisms, TC was significantly positively correlated with $\mathrm{FC}$ and EC at $p \leq 0.01$ level, and the correlation between TC and FC was strong $\left(r^{2}=0.738, p \leq 0.01\right)$. Significant positive correlation was observed between FC and SC and between FC and ENT at $p \leq 0.05$ level. These results are consistent with such variables affecting microbial persistence or fate in rivers.

\section{Land use}

Results of land use analysis indicated that cultivated land was the major type of land in the Haihe River Basin between 1980 and 2008; the Northern China Plain is one of the important food production areas in China. The other three kinds of land use comprised grassland, urban and rural residential/industrial land, and forestland. In the watershed of the three rivers investigated in this study, the major land use type in Zhangjiakou and Tianjin was the cultivated land and in Beijing the forestland (Table 3). In Zhangjiakou, the percentage of grassland and forestland was similar to that of cultivated land, reaching 30.31 and $26.43 \%$, respectively. Forestland, cultivated land, and urban and rural residential/industrial land occupied $89.6 \%$ of Beijing's land, and their proportions were 45, 28.22, and $16.4 \%$, respectively. In Tianjin, however, cultivated land alone occupied $60 \%$ of the area, followed by water area $(14.7 \%)$ and urban and rural residential/ industrial land $(17.9 \%)$.

Land use changes are driven by proximity to expanding city rather than by regional economic trends (Schweizer and 
Fig. 5 Spatio-temporal profile of somatic coliphages (SC)

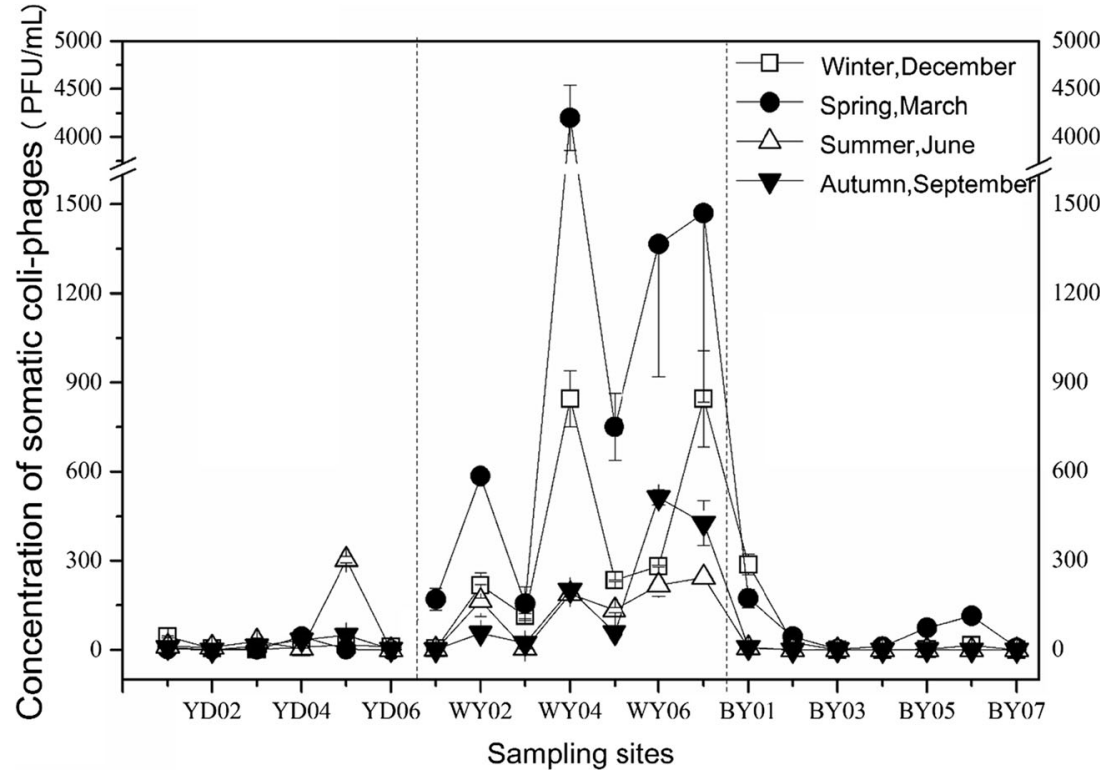

Matlack 2014). Although the major land use types of rivers worldwide vary greatly, all tested FIM are higher in water samples collected in urbanized area. Thus, for the Łyna River located in Poland, the concentrations of FIM varied significantly among the different types of land use (Gotkowska-Płachta et al. 2015). Microbial concentrations were also higher in water samples collected in agricultural area than in those collected in forest areas and grasslands. A study of the southeastern coastline of Florida (Liang et al. 2013) found higher FIM concentrations on urban land and cattle ranch sites; FIM concentrations at most of the sites in this study were consistent with the results presented herein.

The predictive ability on FIM of land use is investigated in many studies, and it should be used carefully. In a densely populated area, such as the Haihe River Basin, the imbalance in the socio-economic development creates a complex microbial pollution; for example, considering the rate of wastewater collection and treatment, although WY03 sample site comprised $49.3 \%$ of urban/ rural residential/industrial land, its pathogenic ratio and concentration were rather low.

\section{Socio-economic development}

The influence of the socio-economic factors such as population density, gross domestic product (GDP), and urbanization rate on the concentration of water pollutants is complex (Moreno et al. 2006; Ren et al. 2003). In this study, population density (people/ $\left.\mathrm{km}^{2}\right)$, GDP (10, $000 \mathrm{RMB}$ ), per capita GDP (RMB/number of people), urbanization rate $(\%)$, percentage of the primary, secondary, and tertiary industry of the GDP were analyzed.
The influence of social and economic factors on microbial contamination in the rivers was further assessed using Pearson correlation analysis (Table 4).

Due to different degree of development, Beijing and Tianjin had similar social and economic characteristics and were significantly different from Zhangjiakou. Population density was the lowest in Zhangjiakou due to its vast mountain range, while Beijing and Tianjin had a high population density as political, economic, and cultural centers. Pearson correlation analysis results show that the concentrations of pathogens were significantly positively correlated with population density and percentage of the

Table 2 Correlation between the concentration of chosen pathogens and water quality indexes

\begin{tabular}{llllll}
\hline Index & TC & FC & EC & ENT & SC \\
\hline Water temperature & 0.189 & 0.072 & 0.207 & 0.201 & -0.098 \\
pH & -0.202 & -0.147 & -0.099 & -0.201 & $-0.288^{* *}$ \\
$\mathrm{DO}$ & -0.205 & -0.176 & -0.047 & -0.126 & $-0.387^{* *}$ \\
Conductivity & -0.023 & -0.045 & 0.011 & -0.047 & -0.08 \\
Turbidity & -0.066 & -0.051 & -0.028 & -0.054 & -0.102 \\
Salinity & -0.022 & -0.044 & 0.014 & -0.045 & -0.076 \\
$\mathrm{COD}^{\mathrm{a}}$ & 0.003 & 0.119 & 0.106 & 0.029 & 0.110 \\
$\mathrm{Phosphate}^{*}$ & 0.149 & $0.235^{*}$ & 0.200 & 0.12 & -0.04 \\
$\mathrm{NH}_{3} \mathrm{~N}$ & 0.159 & $0.274 *$ & 0.116 & 0.214 & $0.273 *$ \\
$\mathrm{NO}_{3} \mathrm{~N}$ & -0.03 & -0.042 & -0.053 & -0.034 & -0.033 \\
Ionic strength & -0.025 & -0.046 & 0.009 & -0.048 & -0.082 \\
\hline
\end{tabular}

Significant correlation coefficient at: $* P \leq 0.05 ; * * P \leq 0.01$

${ }^{\mathrm{a}}$ Correlation analysis between COD and other fecal indicators excludes BY07 
Table 3 Land use of the area located along the three rivers inferred from the visual interpretation of Landsat TM ETM remote sensing images collected between 1980 and 2008

\begin{tabular}{lllllll}
\hline Primary types & CL (\%) & FL (\%) & GL (\%) & WA (\%) & URL (\%) & UL (\%) \\
\hline Yang River (Zhangjiakou) & 26.43 & 30.31 & 1.30 & 1.88 & 0.39 & 39.69 \\
Wenyu River (Beijing) & 44.95 & 7.69 & 2.73 & 16.40 & 0.01 & 28.22 \\
Beiyun River (Tianjin) & 3.64 & 1.66 & 14.75 & 17.90 & 0.48 & 61.58 \\
\hline
\end{tabular}

$C L$ cultivated land, $F L$ forestland, $G L$ grassland, $W A$ water area, $U R L$ urban and rural residents/industrial land, $U L$ unused land

tertiary sector of the GDP but negatively correlated with the percentage of the secondary sector of the GDP. The effect of urbanization rate varied among different pathogens. Currently, studies on the effects of socio-economic development parameters on pathogenic pollution are rarely reported, and most of the research is focused on its effect on physicochemical parameters. For example, Yu et al. (2011) suggested that GDP per capita is significantly negatively correlated with DO but positively correlated with biochemical oxygen demand and $\mathrm{NH}_{3}-\mathrm{N}$. Another study (Pan and Gao 2010) investigated the influence of socioeconomic development on water quality in the Dianchi Lake and found that rapid population growth and economic development is one of the major reasons of lake pollution.

\section{Limitations and future work}

It is important to note that this study was carried out during four field campaigns, in the course of which the FIM varied rapidly. The fluctuations in FIM are possible even in controlled systems at 1-2 log levels. Therefore, to assess the changes throughout seasons, future work should include intensive temporally sampling. The study area is located in a semi-arid region, the annual rainfall was 500-600 $\mathrm{mm}$ in 2014, and prior to all sampling, there were at least seven sunny days; hence, the results were not affected by the rainfall. However, because rain can influence concentrations of studied parameters, additional work should investigate the effects of rainfall and storm events on pathogen loadings in these rivers.
Associations between land uses suggest that urbanized area contributes microbes to rivers. Land use should be focused on the catchment of each river branch, not on the sample point, and socio-economic development should be incorporated. In addition, further work using microbial source tracking is warranted to fully understand pathogen sources in rivers.

\section{Conclusions}

In this large-scale study conducted at 20 locations across the Haihe River Basin in China, the differences between the rivers located in different sections of the watershed and with different land use types and the level of socio-economic development were markedly different. Overall, the concentrations of most pathogens were significantly different in the three types of rivers, reducing the level of surface water quality by one to two grades when including the pathogenic index. The spatiotemporal distribution of pathogens examined and the traditional physical and chemical indicators were significantly different between the three rivers, with the highest values measured in the Wenyu River, followed by the Beiyun River and the Yang River; namely, they decreased from the midstream to downstream and to upstream. Microbial pollution of the river was influenced greatly by water quality indexes, land use types, and the level of socio-economic development. Higher FIM concentrations were often observed in urban land and cattle ranch sites and were positively correlated with population density and percentage of the tertiary industry in GDP. Future studies should focus on the effective management of
Table 4 Pearson correlation analysis between pathogens and socio-economic development parameters in the three river catchments

\begin{tabular}{llllll}
\hline Indexes & SC & TC & FC & EC & ENT \\
\hline Population density & $0.732^{* *}$ & $0.631^{* *}$ & $0.469^{*}$ & 0.148 & $0.506^{*}$ \\
GDP & 0.366 & 0.277 & 0.215 & 0.056 & 0.235 \\
PGDP & -0.184 & 0.176 & -0.151 & -0.130 & -0.160 \\
Urbanization rate & $0.570^{*}$ & $0.567 *$ & 0.462 & 0.377 & $-0.524^{*}$ \\
Percentage of the primary industry in GDP & -0.318 & -0.251 & -0.224 & -0.226 & 0.290 \\
Percentage of the secondary industry in GDP & $-0.596^{* *}$ & $-0.482^{*}$ & -0.412 & -0.135 & -0.423 \\
Percentage of the tertiary industry in GDP & $0.689 * *$ & $0.554^{*}$ & $0.478^{*}$ & 0.225 & $0.517^{*}$ \\
\hline
\end{tabular}

Significant correlation coefficient at: $* P \leq 0.05 ; * * P \leq 0.01$ 
secondary effluent of wastewater treatment plants and land around rivers.

Acknowledgments This study was funded by the National Major Science and Technology Projects for Water Pollution Control and Management (No. 2015ZX07203-005), the "135" Program of Research Center for Eco-Environmental Sciences, Chinese Academy of Sciences (YSW2013B02), the "Twelve-Five" National Science and Technology Support Plan (2012BAJ19B02) and New Century Excellent Talents in University (NCET-12-0531), and the National Natural Science Foundation of China (51478460). We would like to thank Data Center for Resources and Environmental Sciences, Chinese Academy of Sciences (RESDC).

\section{References}

APHA (1998) Standard methods for the examination of water and wastewater, 20th edn. American Public Health Association, Washington

Brookes JD, Antenucci J, Hipsey M, Burch MD, Ashbolt NJ, Ferguson C (2004) Fate and transport of pathogens in lakes and reservoirs. Environ Int 30:741-759. doi:10.1016/j.envint.2003.11.006

Byamukama D, Mach RL, Kansiime F, Manafi M, Farnleitner AH (2005) Discrimination efficacy of fecal pollution detection in different aquatic habitats of a high-altitude tropical country, using presumptive coliforms, Escherichia coli, and Clostridium perfringens spores. Appl Environ Microbiol 71:65-71. doi:10.1120/Aem.71.1.65-71. 2005

Chen Q, Liu J, Ho KC, Yang Z (2012) Development of a relative risk model for evaluating ecological risk of water environment in the Haihe River Basin estuary area. Sci Total Environ 420:79-89. doi: 10.1016/j.scitotenv.2011.09.044

Chen Y, Wang Y, Wei Y, Zheng X, Wang G (2015) Evolution and standard comparison of indicator microorganisms for different surface water. Acta Sci Circumst 35:337-351 (in Chinese)

Chung H, Jaykus LA, Lovelace G, Sobsey MD (1998) Bacteriophages and bacteria as indicators of enteric viruses in oysters and their harvest waters. Water Sci Technol 38:37-44. doi:10.1016/S02731223(98)00797-5

Converse RR, Piehler MF, Noble RT (2011) Contrasts in concentrations and loads of conventional and alternative indicators of fecal contamination in coastal stormwater. Water Res 45:5229-5240. doi:10. 1016/j.watres.2011.07.029

Diaz FJ, O'Geen AT, Dahlgren RA (2010) Efficacy of constructed wetlands for removal of bacterial contamination from agricultural return flows. Agric Water Manag 97:1813-1821. doi:10.1016/j.agwat. 2010.06 .015

EU (2006) Directive 2006/7/EC of the European Parliament and of the Council of 15 February 2006 concerning the management of bathing water quality and repealing Directive 76/160/EEC. Off J Eur Union 2006(L64):37-51

Franke C, Rechenburg A, Baumanns S, Willkomm M, Christoffels E, Exner M, Kistemann T (2009) The emission potential of different land use patterns for the occurrence of coliphages in surface water. Int J Hyg Environ Health 212:338-345. doi:10.1016/j.ijheh.2008. 07.003

George I, Anzil A, Servais P (2004) Quantification of fecal coliform inputs to aquatic systems through soil leaching. Water Res 38: 611-618. doi:10.1016/j.watres.2003.10.022

Gotkowska-Płachta A, Gołaś I, Korzeniewska E, Koc J, Rochwerger A, Solarski K (2015) Evaluation of the distribution of fecal indicator bacteria in a river system depending on different types of land use in the southern watershed of the Baltic Sea. Environ Sci Pollut Res 113. doi:10.1007/s11356-015-4442-6
Heeb F et al (2012) Organic micropollutants in rivers downstream of the megacity Beijing: sources and mass fluxes in a large-scale wastewater irrigation system. Environ Sci Technol 46:8680-8688. doi:10. 1021/es301912q

Hu XJ, Zhang J, Yang YF (2010) Study on the annual changes in water quality and microorganism in the Guangzhou sect of the Pearl River. J Saf Environ 10:89-93 (In Chinese)

ISO (2010) Water quality - detection and enumeration of bacteriophages-Part 2: enumeration of somatic coliphages. vol ISO 10705-2:2000

Kistemann T et al (2002) Microbial load of drinking water reservoir tributaries during extreme rainfall and runoff. Appl Environ Microbiol 68:2188-2197. doi:10.1128/Aem.68.5.2188-2197.2002

Lee GC, Jheong WH, Kim MJ, Choi DH, Baik KH (2013) A 5-year survey (2007-2011) of enteric viruses in Korean aquatic environments and the use of coliforms as viral indicators. Microbiol Immunol 57:46-53. doi:10.1111/j.1348-0421.2012.00515.x

Li M, Hu H, Zhang X, Shen H (2006) Removal of coliphages by wastewater treatment processes. Environ Sci 27:80-84 (in Chinese)

Liang ZB, He ZL, Zhou XX, Powell CA, Yang YG, He LM, Stoffella PJ (2013) Impact of mixed land-use practices on the microbial water quality in a subtropical coastal watershed. Sci Total Environ 449: 426-433. doi:10.1016/j.scitotenv.2013.01.087

Luo Y, Xu L, Rysz M, Wang YQ, Zhang H, Alvarez PJJ (2011) Occurrence and transport of tetracycline, sulfonamide, quinolone, and macrolide antibiotics in the Haihe River Basin, China. Environ Sci Technol 45:1827-1833. doi:10.1021/es104009s

Lv YB, Gong ZY, Lian J, Wang Q, Xing H, Li G (2007) Status of water quality in the Three Gorges after the water storage period Res. Environ Sci 20:1-6 (in Chinese)

Mehaffey MH, Nash MS, Wade TG, Ebert DW, Jones KB, Rager A (2005) Linking land cover and water quality in New York City's water supply watersheds. Environ Monit Assess 107:29-44. doi:10. 1007/s10661-005-2018-5

Mitch AA, Gasner KC, Mitch WA (2010) Fecal coliform accumulation within a river subject to seasonally-disinfected wastewater discharges. Water Res 44:4776-4782. doi:10.1016/j.watres.2010.05. 060

MOE (2003) Ministry of environmental protection, China. The national environment statistical yearbook in 2003. Beijing

MOE (2010a) Ministry of environmental protection, China. The first national pollution census bulletin. Beijing

MOE (2010b) Ministry of environmental protection, China. The national environment statistical yearbook in 2010. Beijing

MOE (2015) Ministry of environmental protection, China. China's environmental bulletin of 2014. Beijing

Moreno JL, Navarro C, De las Heras J (2006) Abiotic ecotypes in southcentral Spanish rivers: reference conditions and pollution. Environ Pollut 143:388-396. doi:10.1016/j.envpol.2005.12.012

Morrison CR, Bachoon DS, Gates KW (2008) Quantification of enterococci and bifidobacteria in Georgia estuaries using conventional and molecular methods. Water Res 42:4001-4009. doi:10.1016/j.watres. 2008.07.021

Pan M, Gao L (2010) The influence of socio-economic development on water quality in the Dianchi Lake. Eng Sci 12:117-122 (in Chinese)

Pernet-Coudrier B, Qi W, Liu H, Muller B, Berg M (2012) Sources and pathways of nutrients in the semi-arid region of Beijing-Tianjin, China. Environ Sci Technol 46:5294-5301. doi:10.1021/es3004415

Pratt B, Chang HJ (2012) Effects of land cover, topography, and built structure on seasonal water quality at multiple spatial scales. J Hazard Mater 209:48-58. doi:10.1016/j.jhazmat.2011.12.068

Ren WW, Zhong Y, Meligrana J, Anderson B, Watt WE, Chen JK, Leung HL (2003) Urbanization, land use, and water quality in Shanghai 19471996. Environ Int 29:649-659. doi:10.1016/S0160-4120(03)00051-5 
Schweizer PE, Matlack GR (2014) Factors driving land use change and forest distribution on the coastal plain of Mississippi, USA. Landsc Urban Plan 121:55-64. doi:10.1016/j.landurbplan.2013.09.003

Sliva L, Williams DD (2001) Buffer zone versus whole catchment approaches to studying land use impact on river water quality. Water Res 35:3462-3472. doi:10.1016/S0043-1354(01)00062-8

St Laurent J, Mazumder A (2012) The influence of land-use composition on fecal contamination of riverine source water in southern British Columbia. Water Resour Res 48 doi:10.1029/2012wr012455

Tong STY, Chen WL (2002) Modeling the relationship between land use and surface water quality. J Environ Manag 66:377-393. doi:10. 1006/jema.2002.0593

USEPA (1985) United States Environmental Protection Agency. Test method for Escbericbia and enterococci in water by the membrane filter procedure. Cincinnati, $\mathrm{OH}$

USEPA (2012) United States Environmental Protection Agency. Recreational water quality criteria. Office of water 820-F-12-058. Health and Ecological Criteria Division

Walters SP, Thebo AL, Boehm AB (2011) Impact of urbanization and agriculture on the occurrence of bacterial pathogens and stx genes in coastal waterbodies of central California. Water Res 45:1752-1762. doi:10.1016/j.watres.2010.11.032

WHO (2000) World Health Organization. Monitoring bathing waters - a practical guide to the design and implementation of assessments and monitoring program. F \& FN Spon, London

WHO (2009) World Health Organization. Global health risks: mortality and burden of disease attributable to selected major risks. WHO Press, Geneva

Yang RQ, Lv AH, Shi JB, Jiang GB (2005) The levels and distribution of organochlorine pesticides (OCPs) in sediments from the Haihe River, China. Chemosphere 61:347-354. doi:10.1016/j. chemosphere.2005.02.091

Yang Y, Yang Y, Wei YS, Zheng X, Wang YW, Yu M, Xiao QC, Yu DW, Sun C, Yang Y, Gao LJ (2012) Investigation of microbial contamination in Wenyu River of Beijing. Acta Sci Circumst 32:9-18 (in Chinese)

Yu M, Wei YS, Liu JG, Liu PB, Zhang ZM, Wei W, Wang YW, Zhong J, Yang Y, Xiao QC (2011) Impact of socioeconomic development on water resource and water environment of Yongding River in Beijing. Acta Sci Circumst 31:1817-1825 (in Chinese) 